\title{
Impact Of Covid-19 Pandemic On Trade And Development In Developing Countries
}

\author{
Wanjiku Musili \\ Cooperative University of Kenya P. Box 24814-00502 Nairobi \\ DOI: 10.29322/IJSRP.11.04.2021.p11208 \\ http://dx.doi.org/10.29322/IJSRP.11.04.2021.p11208
}

\begin{abstract}
The last quarter and the first quarter of 2019 and 2020 respectively the world experienced the emergence of the novel coronavirus. This is a "severe acute respiratory syndrome coronavirus-2 (SARS-CoV-2)" caused by a highly contagious disease that referred by scientists as "coronavirus disease 2019 (COVID-19)." On $6^{\text {th }}$ December 2019, China reported the first case of the disease in Wuhan City. After three months the disease had spread widely across the globe making the World Health Organization (WHO) to declare it a global pandemic on $11^{\text {th }}$ of March, 2020. So far, the pandemic have wreaked havoc in both developed and developing economies. Poor nations, especially in the African region, have born the blunt of the pandemic. The focus of this review was on the world's poorest region, Africa. Many countries responded by implementing public health measures to curb the spread of COVID-19 and manage cases within their respective jurisdictions. African countries have not recorded high number of cases and deaths as initially projected. However, there is little or no evidence to link the public health measures adopted with the low number of cases and deaths reported. Therefore, the focus of this study was on COVID-19 susceptibility, readiness to tackle the disease and its economic impact on the developing nations in Africa. Secondary data was used and a total of twenty (20) studies were reviewed and reports from the World Health Organization and other United Nations' arms were included. This study revealed that the goal of the public health measures that included containment and travel restrictions was to lower the rate of transmission of the virus via direct contact with infected people. However, these control protocols have significantry exposed the developing nations to economic crisis. This study also highlights that although the virus infect people indiscriminately, there is disprportionate socioeconomic impact on specific sectors of the economy. Besides, vulnerable groups in the society are more affected than other people. For quick and sustainable recovery the governments in developing countries should collaborate through financial resources needed for: cushoning the most affected groups and provide social security through social protection programs. This study recognised that women are more likely to be affected than men and recommends that supporting entrepreneurial environment for them would greatly improve their livelihoods.
\end{abstract}

Keywords: COVID-19 Impact, Trade and Development, Vulnerability, Developing Nations

\section{INTRODUCTION}

COVID-19 or SARS-CoV-2 virus is the scientific term given to the novel coronavirus that causes a severe respiratory disease. It originated from Wuhan City in China at the end of 2019 and by first quarter of 2020, the virus had spread across the world prompting the World health Organization to declare a global pandemic (WHO, 2020). The rate of spread and the level of disruptions associated with the disease has shocked people globally. Many people have lost their lives since the COVID-19 emerged, others are battling the disease in hospitals and homes while many others have lost their livelihoods. COVID-19 has devastated global economy and it is expected to shrink by $4.3 \%$. This means that if the disease continues to spread and adversely affect more people, millions of jobs will be lost and extreme poverty will increase (UNCTAD, 2020).

Although COVID-19 started in Asia and moved to adversely impact North America and European countries before getting into Africa, the latter is the most vulnerable due to weak healthcare systems and large proportions of vulnerable groups in her population (Shabir Ahmad Lone and Aijaz Ahmad, 2020). Many people are poor and may not have the means to adequate nutrition for a wellfunctioning immune system. Besides, the continent already has other significant disease burdens as a result of HIV/AIDs, malaria, and tuberculosis. The situation is exacerbated by precarious economic conditions in the continent. Africa was already in economic problems when COVID-19 emerged (World Economic Forum, 2020). The continent is in dire need of COVID-19 response strategies that take cognizance of its unique circumstances and vulnerabilities (United Nations Human Rights, 2020).

The public health measures taken by countries to curb the spread of the virus have adverse economic consequences. Most notable of them are the loss of livelihoods for many daily wage workers, small scale entrepreneurs, and workers in the hospitality industry. The pandemic has also adversely affected vulnerable populations such as people living with HIV/AIDs (Jewell B, Mudimu E, Stover J, et al, 2020). After reporting her first case on March 13, 2020, Kenya imposed a nationwide curfew and later travel restrictions among other policy guidelines to stop or slow down the spread of the virus. The travel restrictions significantly affected the tourism, This publication is licensed under Creative Commons Attribution CC BY. 
hospitality and horticultural sectors. Many Kenyans in the cities and towns made efforts to migrate to their rural homes, where cost of living is lower, as live became unbearable in cities and towns due to loss livelihoods.

\section{MAIN ARGUMENT}

\subsection{The Impact on Developing Economies}

COVID-19 first ravaged developed countries and now is spreading fast in the developing countries. As experts at the United Nations and World Health Organization have expressed, there are concerns that the pandemic will leave irreversible and long-term effects in developing nations (UNDP, 2020; WHO, 2020). These countries are poor with inadequate infrastructure and rely on production of raw materials for industries in North America, Europe, and Asia. With disruptions occasioned by the pandemic in the developed countries demand for raw materials will decline hence little or no income from natural resources, agriculture, and mining sectors in the developing countries (World Bank, 2020).

\subsection{The impact on poorer countries right now}

Due to financial difficulties associated with COVID-19, many developing countries have sought emergency funding from the International Monetary Fund (IMF). It is estimated that approximately 90 countries have requested financial assistance from the IMF while about 24 of them beneficiaries of immediate debt relief (IMF, 2020). In the Sub-Saharan Africa, for instance, COVID-19 has damaged the economy through disruptions of the supply chains, earnings from commodities have plummeted due to low demand, foreign investors have exited the market, and the tourism sector is on its knees (Tomasz Michalski, 2020).

\subsection{The projected future impact on developing economies}

The bad situation in the developing countries could see workers immigrate to developed countries to look for work as opportunities diminish locally. This could deprive developing countries the much needed labour to facilitate their recovery and create problems in developed countries as they absorb the high number of immigrants. The developing countries may take longer to recover and may experience challenges such as widespread state failure and hunger. This situation could make it hard for the developing countries to repay their loans (Maliszewska, Maryla and Mattoo, 2020).

\subsection{Impact on trade and development}

The World Bank in their article "Global pandemic" scenario, they highlighted that the contagion has led to developments that could have adverse effects. Among these developments include labour underutilization of 3\% in all sectors, decrease in capital usage, $25 \%$ rise in global import and export costs, decline in tourism affecting related sectors and low demand, especially in sectors that require human interactions (World Bank, 2020). COVID-19 emergence at the backdrop of poverty in developing nations pose a great risk to vulnerable populations that are barely surviving. Africa has many countries that have been embroiled in conflicts for years and could find it hard to withstand this pandemic (Newell and Simon, 1972). It will add more misery to their already delicate situations. The disruptions occasioned by the pandemic means that the level of poverty in developing countries in Africa could skyrocket.

\subsection{Summary and Gaps}

The literature reviewed shows the impact of covid-19 on the global economy and the developed nations. Mukhisa Kituyi et al (2020) explains the effects of covid-19 in the UNCTAD "Transitioning to a New Normal" special publication, as economies being brought down to knees. However, the key current and expected trade and development impacts in developing nations have not yet been captured. All the studies have been focusing on transition to the new normal, forgetting the vulnerability of the developing nations. This can be attributed to overemphasis on containment measures which have been adopted by most governments across the globe. Poverty, rise of social vices such as crime, gender based violence, prostitution and increase of HIV infections are all linked to covid19. There is need to delve deeper to comprehensively understand the impacts of covid19 pandemic on trade and development of developing nations. This study thus sought to fill in this knowledge gap.

\subsection{Aim of this review}

There are several outstanding published materials around the world on the pandemic. The goal of this review is to provide a comprehensive update on the disease in developing nations in Africa, their susceptibility the disease, readiness to tackle it and the economic consequences of the pandemic. The review could be helpful in conducting future studies and shed light on the hardships experienced by the continent in the course of the pandemic.

\section{METHODOLOGY}

\subsection{Study selection}


This study reviewed articles published between January 2020 to January 2021 in three academic databases namely PubMed, Science Direct and Scopus. Only articles written in English were considered in this study. Three search terms were used and they included coronavirus, COVID-19, and SARS-CoV-2. Two people were engaged in the search to ensure reproducibility. The search yielded 71 articles but excluding publications that were not relevant to the issue at hand and those in other languages, 20 articles were selected for review. Table 1 summarizes the distribution of retrieved and selected articles by journal platform. Besides published articles, WHO and CDC updates and reports were included.

Table 1: Distribution and Selection of Articles

\begin{tabular}{lll}
\hline Journal Article Platform & Retrieved Articles & Selected Articles \\
PubMed & 15 & 5 \\
Science Direct & 30 & 10 \\
Scopus & 26 & 5 \\
Total & $\mathbf{7 1}$ & $\mathbf{2 0}$ \\
\hline
\end{tabular}

Thematic analysis method was employed to review twenty (20) journal articles. The results of this study were used to discuss the key theme of this study; Impact of COVID-19 in trade and development of vulnerable developing nations, with an emphasis on the pandemics, epidemiology, vurnerability of developing nations and the actual impact on developing nations in Africa.

\section{FINDINGS}

\subsection{Epidemiology of COVID-19 in Africa}

The epicenter of COVID-19 is believed to be Wuhan City, the capital of Hubei province in China. As one of the greatest pandemics in human history, it had spread globally in a record time of less than three months (Du Toit A, 2020). As at March 2021, the pandemic is still active with changing number of infections, deaths and recoveries daily. COVID-19 started at diverse periods in different countries hence these countries are also at different stages in management of the pandemic. By April 2020, the pandemic had reached all the seven continents in the world with 213 countries affected, 2,121,675 infected people and a death rate of 6.7\% (World Health Organization, 2020). The United States of America, India, and Brazil were the most affected countries globally by March 2021. Their infections were 29599380, 11204179, and 10871843 respectively (WHO, 2021).

The available data shows that the African continent was the last to be affected by the pandemic and has the least confirmed infections of COVID-19 (Euractiv, 2020). As of $6^{\text {rd }}$ March 2021, Africa reported 3,977,788 infections from 57 countries with a relatively low mortality rate $(C D C, 2021)$. On February $14^{\text {th }}$ 2020, the first infection in Africa was reported in Egypt followed by Algeria on February $25^{\text {th }}$ and Nigeria on February $27^{\text {th }}$. In March 2021, almost all the countries in the African continent have reported COVID-19 infections (WHO, 2020). The countries with the most confirmed infections of COVID-19 in Africa are South Africa, Morocco and Tunisia. Their confirmed infections as at $6^{\text {th }}$ of March were 1518978,485567 , and 236356 respectively (CDC, 2021). Inadequacy and lack of capacity to test many people have led to concerns that the reported infections may not reflect the reality. Given these circumstances, it is hard to assess the true epidemiology of COVID-19 with certainty in the African continent. Several factors are expected to shape the epidemiology of COVID-19 in Africa. These factors include the late arrival of COVID-19 pandemic as compared to other continents, poor capacity to detect the disease, inadequate medical supplies and equipment, and a large proportion of the vulnerable population (Africa Center for Strategic Studies, 2020). Table 2 presents COVID-19 data by country, confirmed infections, deaths, recoveries and the date that first cases were confirmed in each country (World Health Organization, 2021).

Table 2. Epidemiology of COVID-19 cases in Africa as at ${ }^{\text {rd }}$ of March, 2021.

\begin{tabular}{|l|l|l|l|l|}
\hline Country & Confirmed cases & Deaths & Recoveries & First cases \\
\hline Algeria & 113,948 & 3,007 & 78,824 & $25^{\text {th }}$ February, 2020 \\
\hline Angola & 21,026 & 511 & 19,624 & $21^{\text {st }}$ March, 2020 \\
\hline Benin & 6,071 & 75 & 4,963 & $16^{\text {th }}$ March, 2020 \\
\hline Botswana & 31,746 & 359 & 26,760 & $30^{\text {th }}$ March, 2020 \\
\hline Burkina Faso & 12,123 & 143 & 11,722 & $9^{\text {th }}$ March, 2020 \\
\hline Burundi & 2,283 & 3 & 773 & $31^{\text {st }}$ March, 2020 \\
\hline Chad & 4,089 & 140 & 3,572 & $19^{\text {th }}$ March, 2020 \\
\hline Cameroon & 35,714 & 551 & 32,594 & $6^{\text {th }}$ March, 2020 \\
\hline Cape Verde & 15,683 & 152 & 15,007 & $20^{\text {th } \text { March, 2020 }}$ \\
\hline Central Africa & 5,018 & 63 & 4,920 & $14^{\text {th }}$ March, 2020 \\
\hline
\end{tabular}

This publication is licensed under Creative Commons Attribution CC BY. 


\begin{tabular}{|c|c|c|c|c|}
\hline Comoros & 3,587 & 145 & 3,389 & $15^{\text {th }}$ May, 2020 \\
\hline Congo & 9,179 & 131 & 7,514 & $10^{\text {th }}$ March, 2020 \\
\hline D.R.C & 26,469 & 712 & 22,432 & $10^{\text {th }}$ March, 2020 \\
\hline Djibouti & 6,134 & 63 & 5,931 & $18^{\text {th }}$ March, 2020 \\
\hline Egypt & 185,334 & 10,916 & 143,143 & $14^{\text {th }}$ February, 2020 \\
\hline Equatorial guinea & 6,329 & 96 & 5,737 & $14^{\text {th }}$ March, 2020 \\
\hline Eritrea & 2,944 & 7 & 2,436 & $20^{\text {th }}$ March, 2020 \\
\hline Eswatini & 17,155 & 654 & 15,131 & $14^{\text {th }}$ March, 2020 \\
\hline Ethiopia & 164,073 & 2,404 & 137,431 & $13^{\text {th }}$ Mar, 2020 \\
\hline Gabon & 15,625 & 90 & 13,495 & $12^{\text {th }}$ March, 2020 \\
\hline Gambia & 4,759 & 152 & 4,143 & $17^{\text {th }}$ March, 2020 \\
\hline Ghana & 86,092 & 640 & 80,619 & $12^{\text {th }}$ March, 2020 \\
\hline Guinea & 16,420 & 93 & 15,091 & $13^{\text {th }}$ March, 2020 \\
\hline Guinea-Bissau & 3,303 & 96 & 5,737 & $25^{\text {th }}$ March, 2020 \\
\hline Ivory coast & 34,412 & 199 & 32,354 & $11^{\text {th }}$ March, 2020 \\
\hline Kenya & 108,362 & 1,874 & 87,550 & $12^{\text {th }}$ March, 2020 \\
\hline Lesotho & 10,523 & 307 & 3,888 & 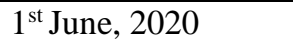 \\
\hline Liberia & 2,023 & 85 & 1,884 & $16^{\text {th }}$ March, 2020 \\
\hline Libya & 137,482 & 2,236 & 124,712 & $24^{\text {th }}$ March, 2020 \\
\hline Madagascar & 19,831 & 297 & 19,296 & $20^{\text {th }}$ March, 2020 \\
\hline Malawi & 32,357 & 1,063 & 21,621 & $2^{\text {nd }}$ April, 2020 \\
\hline Mali & 8,509 & 358 & 6,435 & $25^{\text {th }}$ March, 2020 \\
\hline Mauritania & 17,285 & 422 & 16,645 & $13^{\text {th }}$ March, 2020 \\
\hline Mauritius & 625 & 10 & 588 & $19^{\text {th }}$ March, 2020 \\
\hline Mayotte & 18,140 & 126 & 2,964 & $14^{\text {th }}$ March, 2020 \\
\hline Morocco & 485,567 & 8,673 & 471,410 & $2^{\text {nd }}$ March, 2020 \\
\hline Mozambique & 61,529 & 680 & 45,884 & $22^{\text {nd }}$ March, 2020 \\
\hline Namibia & 39,676 & 437 & 37,259 & $14^{\text {th }}$ March, 2020 \\
\hline Niger & 4,740 & 172 & 4,250 & $19^{\text {th }}$ March, 2020 \\
\hline Nigeria & 158,042 & 1,954 & 137,025 & $27^{\text {th }}$ February, 2020 \\
\hline Reunion & 13,125 & 59 & 11,956 & $12^{\text {th }}$ March, 2020 \\
\hline Rwanda & 19,426 & 267 & 17,751 & $14^{\text {th }}$ March, 2020 \\
\hline $\begin{array}{l}\text { Sao-Tome-and- } \\
\text { Principe }\end{array}$ & 1,938 & 31 & 1,544 & $6^{\text {th }}$ April, 2020 \\
\hline Senegal & 35,632 & 907 & 30,369 & $2^{\text {nd }}$ March, 2020 \\
\hline Seychelles & 2,950 & 15 & 2,610 & $14^{\text {th }}$ March, 2020 \\
\hline Sierra Leone & 3,909 & 79 & 2,658 & $31^{\text {st }}$ March, 2020 \\
\hline Somalia & 8,041 & 294 & 3,932 & $16^{\text {th }}$ March, 2020 \\
\hline South Africa & $1,518,979$ & 50,566 & $1,437,050$ & $5^{\text {th }}$ March, 2020 \\
\hline South Sudan & 8,677 & 102 & 4,317 & $5^{\text {th }}$ April, 2020 \\
\hline Sudan & 28,545 & 1,895 & 23,084 & $13^{\text {th }}$ March, 2020 \\
\hline Tanzania & 509 & 21 & 183 & $16^{\text {th }}$ March, 2020 \\
\hline Togo & 7,428 & 88 & 6,173 & $6^{\text {th }}$ March, 2020 \\
\hline Tunisia & 236,356 & 8,130 & 201,500 & 2nd March, 2020 \\
\hline Uganda & 40,452 & 334 & 15,065 & $20^{\text {th }}$ March, 2020 \\
\hline Western Sahara & 10 & 1 & 8 & $5^{\text {th }}$ April, 2020 \\
\hline Zambia & 82,011 & 1,116 & 77,609 & $18^{\text {th }}$ March, 2020 \\
\hline Zimbabwe & 36,248 & 1,484 & 33,759 & $15^{\text {th }}$ March, 2020 \\
\hline Total & $\mathbf{3 , 9 7 8 , 4 4 3}$ & 105,458 & $3,541,251$ & \\
\hline
\end{tabular}

\subsection{Vulnerability in Developing Nations}

Many of the most vulnerable countries to COVID-19 are in Africa. Based on Infectious Disease Vulnerability Index of 2016, there are 25 countries that are most susceptible to COVID-19 worldwide. Twenty two of them (88\%) are in Africa (WHO, 2020). People with non-communicable and communicable diseases is high in Africa. According to WHO (2019), there are 213 million people with malaria, 71 million with hepatitis B and C, 26 million with HIV/AIDs, and two and a half million people with tuberculosis. These diseases adversely affect their immunity and exposes them to higher risks than the normal population in case of contracting COVID- 
19 (Mudie K, Tan MMJ, Kendall L, et al, 2019). It is therefore safe to conclude that the largest proportion of the population in Africa are at a high risk of severe symptoms if they were to be infected by COVID-19 due to their unstable immunity courtesy of high prevalence of other diseases.

Mo Ibrahim (2020) highlighted that healthcare capacity is critical in the management and control of COVID-19 management. The developed countries like the UK and USA have better health care systems than most African countries. However, they have struggled to manage and control the pandemic due to its magnitude. This makes one wonder what will happen to the African countries who have weaker health care systems compared to developed countries (OECD Development Matters, 2020). The problems in developing countries in Africa when it comes to management and control of COVID-19 are complex. They are characterized by inadequate capacity to test many people, low number of health care workers, lack of ventilators, and few intensive care units to manage patients who get severe symptoms from COVID-19.

Resources and prioritization in the health care sector are expected to determine the capacity of African countries in dealing with the pandemic. Nachega JB, Seydi M and Zumla A, (2020) observed that most of the African countries do not have the requisite medical supplies and equipment to fight against the disease. Their health care workers, for instance, have a shortage of personal protective equipment because the health sector in Africa is largely underfunded. This makes many African countries vulnerable to COVID-19 pandemic. Another challenge for the African countries in the north and south of the equator is the weather changes that could complicate issues in the fight against COVID-19. During the cold season in winter, the prevalence of respiratory diseases is high and they spread faster than in the warm season. The cold season is therefore likely to increase the intensity of COVID-19. In the summer, the intensity of COVID-19 could decrease (Mendelson M, 2020; McKenzie B, 2020).

The development and growth of African countries will be adversely affected by COVID-19 (Center for Global Development, 2020). The pandemic has already presented a significant challenge for the developed countries who enjoy advanced health care systems and infrastructure. Their economies have shrank due to the pandemic and the recovery is slow as they fight the disease. The situation is expected to be worse for the African countries who have weak health care systems and poor infrastructure. Some of the economies in Africa may collapse as the pandemic persists. This could lead to political instabilities and conflicts. The situation in each country, however, will be shaped by context and measures put in place for the management and control of the pandemic.

At the onset of the pandemic, studies correctly predicted the susceptibility of African countries to COVID-19. A study by Gilbert M, Pullano G, Pinotti F, et al. (2020) revealed that South Africa, Algeria, had the highest likelihood to import the virus from China and developed countries and moderate capacity to handle the pandemic. Nigeria and Ethiopia were shown to have moderate likelihood of importing the virus to Africa and a weak capacity to handle the pandemic. Other countries that were reported to have moderate importation risk and variable capacity to handle COVID-19 were Kenya, Ghana, Sudan, Angola, and Tanzania. The study concluded that overall, many countries in Africa were highly vulnerable to the pandemic. However, the structure of the population in Africa largely comprising of young people is likely to favor the African continent compared the developed countries whose population structures are largely comprised of older people.

COVID-19 have been seen to affect older people more than the young. Higher mortality rate have been recorded in older people than young people. Besides, older people get severe symptoms more than the young people who get mild symptoms. According to Mo Ibrahim Foundation (2020), the African continent has the youngest median age of 20 years. People older than 65 years are only $4 \%$ of the population in Africa as compared to 29\% and 37\% in Europe and North America and Eastern and South-Eastern Asia respectively (World Population Ageing, 2019). Given that the pandemic arrived in Africa last, the continent had more time to prepare than the rest of the world. Besides, Africa had learnt lessons from Asia, North America and Europe who had already encountered the pandemic before it spread to the African continent. Africa have had other outbreaks but of lower proportions like Ebola in 2014 which could have also provided lessons to address COVID-19 pandemic. The governments in Africa imposed measures variably that included travel restrictions, school closures, gatherings ban, quarantine of infected people, lock downs, and enhancing capacity for testing and management of infected people (International Monetary Fund, 2020).

On $5^{\text {th }}$ February 2020, the Africa Centre for Disease Control in partnership with the African Union Commission (AUC) and the WHO established the African task force for coronavirus (AFCOR). The goal of this taskforce was to enhance the continent's readiness for fighting COVID-19 pandemic (CDC, 2020). The mandate of AFCOR is to concentrate on six key areas that include surveillance and diagnosis, prevention and control of the infections at health facilities, treatment of COVID-19 patients who present severe symptoms, dissemination of information on risks, and ensuring seamless medical supplies and equipment. A major achievement for AFCOR was facilitating 43 countries in Africa to have the capacity to test COVID-19 in less than a month. By February 2020, only Senegal and South Africa had the capacity to diagnose the virus (Mo Ibrahim Foundation, 2020).

The African countries received tremendous support for preparedness and responding to COVID-19 from their development partners such as the World Bank. Ethiopia and the Democratic Republic of Congo, for instance received immediate support of $\$ 82$ million and $\$ 47$ million respectively (World Bank, 2020). Other African countries also received support to fight the virus. Besides, several non- 
governmental organizations, philanthropists, development agencies, and the private sector pooled resources for preparedness in the fight against COVID-19. Despite this overwhelming support, Africa owing to her unique circumstances and context still require more support to tackle the virus and the resultant socio-economic consequences.

\subsection{Economic impact of COVID-19 in developing nations in Africa}

According to Jaramillo (2010) different types of crisis present diverse socio-economic situations. The extent of destruction caused by a crisis plays a major role in shaping the consequences. Pandemics are less common compared to other disasters. It is therefore hard to predict them as well as managing and controlling the destruction that they cause (Skidmore and Toya, 2002).

At the beginning of the pandemic, the focus was on the epidemiology of the disease but this has changed as the pandemic persists. The attention now is on the destruction that the pandemic has visited on the global economy. However, there is need to also focus more specifically to the devastation that the developing countries in Africa have suffered in the course of the pandemic. Economic experts have observed that the previously estimated economic growth in Africa of 3.9\% cannot be achieved. They have revised their projections to the best case scenario of $0.4 \%$ and the worst case scenario of $-3.9 \%$ (African Development Bank Group, 2020). The Sub-Saharan Africa could be worse with projections of -2\% to -5\%. The impact of COVID-19 on the African continent could see the region or some countries in Africa suffering recession (World Bank, 2020).

The COVID-19 pandemic have led to several consequences on the African economy. One of the major consequences is food insecurity. The measures taken by governments to curb the spread of the virus have significantly disrupted the supply chains hence affecting food availability. In Kenya, for example, public health protocols, closure of markets, partial lockdowns and curfew has affected availability of food. The poor were the most affected by these measures as they source most of their products from markets. The middle income earners however were less affected as they source their products from supermarket stores that were not closed. The same case applied to the small scale transporters who were affected by travel restrictions and lockdown as opposed to established logistics companies that were allowed to operate (Ayieko and Njeru, 2020).

The disproportionate socio-economic impact of the pandemic was not limited to the different categories of transporters and consumers but went further to gender. COVID-19 has threatened to roll back achievements made in gender equality and women empowerment. Although the mortality rate of men have been established to be higher than that of men, the resultant socio-economic conditions have affected women more than men in many ways. Several justifications could be attributed to this state of affairs and they include:

1. Most women have no job security as they are in part-time employment contracts and now with the pandemic, they are more likely to lose their jobs than men (Durant and Coke Hamilton, 2020).

2. Since men in formal employment are more than women, it also means that women with social protection are few as compared to many men who have social protection in Africa. The number of women in informal employment is approximately $90 \%$ compared to $83 \%$ of men in informal employment (ILO, 2018). Informal employment does not offer social security and it means that most women do not have health insurance, cannot get sick leave, maternity leave, pension, and other benefits. In the first months of the pandemic UN-Women (2020) estimated that earnings for women working in the informal sector shrank by $60 \%$.

3. Sectors that are dominated by women are the most hit by the pandemic. For example tourism and hospitality industry. Travel restrictions and social distancing rules have led to closure of many businesses in the services sector. This sector employs 55\% women and $45 \%$ men. It is therefore safe to conclude that women employment was adversely affected by the pandemic than that of men (ILO, 2020).

4. The containment measures and policies adopted by developing nations such travel restrictions and seclusion have amplified domestic conflicts. The situation has been exacerbated economic hardships at the household and individual levels. There is lack of data in many countries due to poor reporting systems. However, countries with better reporting systems have shown that domestic violence cases increased by $25 \%$ as a result of this pandemic which could be an underrepresentation of the real situation (UN-Women, 2020).

5. Many women entrepreneurs in developing countries rely on credit to operate their businesses. COVID-19 negatively affected their businesses hindering their ability to repay loans damaging their reputation which make it hard for them to access loans in future. Without loans that offer a lifeline to many women entrepreneurs, it means they will have to close their businesses losing a livelihood not only for themselves but also for the people they employed.

The pandemic have caused foreign investors in the developing countries to exit market. This has denied these countries the much needed foreign direct investments. The decline in foreign direct investment flows have adversely affected the economies of the developing countries. With less capital in circulation, the level of economic activities decreases and unemployment soars (International Monetary Fund, 2020). Since the pandemic is worldwide, the flow of aid and donor assistance to the developing countries in Africa has also declined. Many donor projects have stalled and employment for many people is in limbo. 
The pandemic has led to increased job losses and decreased productivity. There is also a risk of increased burden of unpaid on women. As many people work from home and women are culturally assigned the role of caring for the other family members in most patriarchal societies, women may be overwhelmed by household chores. Besides, women make the largest proportion of healthcare workers. They are therefore more exposed to the virus at work than men (International Labour Organization, 2020).

African Union report (2020) highlighted that the pandemic has greatly reduced the tourism sector. The economies of many of the countries like Kenya, South Africa, Ethiopia, and Tanzania are heavily reliant on the tourism sector. Travel restrictions and cancelation of many events across the world have negatively affected tourism sector in developing countries. The pandemic have wreaked havoc on the tourism sector and many facilities in the sector have had to close down. The loss of jobs in the tourism sector and the related businesses is monumental (United Nations, 2020).

McKenzie B, (2020) acknowledged that that mining industry is the major motivation for China's investments in Africa. The pandemic caused a lot of supply chain disruptions due to lockdowns, travel restrictions and other containment measures. The demand for the raw materials China sources from African countries have therefore plummeted as a result of the pandemic. In South Africa, for instance, approximately 420,000 people are employed in the mining industry. Their work environment is enclosed and could pose risks of COVID-19 infections and spreading of the virus (Mining Review Africa, 2020). This has led to restrictions that have adversely affected the mining sector. Besides, the level of oil consumption went down as a result of the pandemic. Travel restrictions, lockdowns and border closures have seen low oil consumption around the world. This have adversely affected countries whose budget heavily rely on oil like Nigeria, Algeria, Ghana, and Angola (African Union, 2020). The declined in oil prices could be helpful to net oil importers like Kenya.

The pandemic significantly affected small scale enterprises. McKinsey, (2020) noted that at least two of three jobs at risk are in Small and Medium Enterprises (SMEs). These SMEs form a critical part of the developing countries' economies. Their stagnation, collapse or high job losses due to the pandemic severely affects many other sectors. International Labour Organization projects that there will be decreased productivity worldwide as a result of the pandemic. This has implications for the already vulnerable small scale enterprises.

Past studies have shown that natural crisis have unpredictable influence on the relationship between economic growth and human capital. According to Toya et al. (2010), when a crisis affect a large proportion of the population, it adversely affect efficiency of labour production. It also inhibits the process of human capital accumulation. These two situations lead to declining economic growth.

The reallocation of resources from other sectors of the economy to the health sector will significantly affect economies of the developing countries. This reallocation of resources is due to the weak health care systems in Africa. As Mark et al. (2020) highlighted, many people do not have access to health services in Africa. The COVID-19 pandemic has prompted governments, development partners, and other stakeholders to focus on strengthening the weak healthcare systems. This could lead to neglect of other sectors and decline in economic growth for many African countries.

\section{CONCLUSION AND RECOMMENDATIONS}

\subsection{Conclusion}

This review examined the impact of COVID-19 on trade and development of developing nations in Africa. It acknowledges that the impacts of coronavirus are both immediate and lasting, which is a wake-up call for policymakers of developing countries in Africa. The pandemic's short-term and long-term effects should be addressed in order to ensure quick recovery. This involves supporting increased manufacturing and trade in Africa to foster economic immunity against such economic shocks in the future. Besides, effective policies that will avail modern factors of production such as technology, human capital and funding are necessary to support the economies of developing nations.

The combined protocols of pandemic related countering strategies and policies could have permanent effects on the way people interact and their movement. Travel restrictions and curfews could become permanent limiting movement of migrants and labour from one market to another. This may require collaboration among affected countries and regions to ensure standardized measures that will support development.

Moreover, the African countries cannot fight COVID-19 in isolation hence the need to collaborate with others for a global solution. The African countries have to seek resources and technical support for addressing the health and socio-economic challenges occasioned by the pandemic. Developing countries in Africa also have to re-examine the immediate public health measures adopted to 
curb the spread of the virus as they could pose lasting adverse effects on their economies. International coordination is critical in the fight against the pandemic if the developing countries are to win not only against COVID-19 but also the devastation it has caused in many countries.

Developing countries should come up with ways of increasing domestic food production to address the impact of food crisis and insecurity. They should also make strategies and policies to ensure equitable access to food as this has a critical role in nutrition and health of their populations. A healthy population has higher immunity than an unhealthy one and it is less exposed to the virus. Apart from food production, other factors such as processing, storage, and distribution play a significant role in food availability. The food security policies should therefore take into account all the necessary factors to ensure all sections of a population are able to access food.

Minimizing women discrimination in regards to financial inclusion can enhance their economic engagements and reduce their vulnerability brought by the pandemic. This will also ensure that their businesses that could be the only remaining source of livelihood do not close down. New innovations that lower cost of doing business and cost of financing should also be embraced. Digital platforms have proved to be important to avoid handling of cash and have contributed significantly in reducing contact with contaminated materials.

Developing countries in Africa should enhance the voice of women and their participation in development. Women should be engaged more in decision making to ensure issues that affect them and their communities are adequately addressed. Women have played a critical role in the fight against the pandemic. Their capacity should be improved to enable them grow and assist their families cope with the pandemic. Promotion of education for women and girls as well as training them to impart skills could help many of them shift from the informal sector that has no social security to the formal sector. There is a need for social safety nets for the vulnerable people in developing countries to mitigate suffering resulting from the pandemic. This will prevent more people in the society slipping into poverty. Growth and capacity building of productive sectors that offer employment such as the SMEs is necessary for the developing countries to sustain their economies and curb increasing levels of poverty.

Coronavirus can be seen as prompting developing countries in Africa to prioritize their ailing health care systems. Their high susceptibility to infectious diseases, high level of poverty, poor infrastructure and weak health care systems are some of the factors that exposes developing countries in Africa to COVID-19 pandemic. The change of weather to winter could also significantly affect developing countries in the north and south hemispheres. Cold seasons or winter come with increased flu which could increase COVID-19 infections.

\subsection{Recommendations}

This study outlined the following recommendations:

1. Integrated regional governments should collaborate through pooling of resources to counter the CIVID-19 pandemic for quick and sustainable recovery.

2. The countries should increase the economic stimulus packages, in order to cushion the most affected subjects in order to return to the pre-COVID-19 livelihoods.

3. Accelerating the gender equality policies, programs and campaigns and create a conducive environment for women entrepreneurship.

4. Governments and donors should invest adequately in the preparedness to respond to the economic damage created by the pandemic.

5. Introduction of social safety nets is necessary where they do not exist and also strengthening those that are in place.

6. The provision of low-interest loans and debt relief is good policy option that should increase investment and rise of economic activities for quick recovery of the economies of developing countries

7. There is need for the government to invest in manufacturing and trade sectors to ensure an economic environment that can persevere shocks like COVID-19.

8. The governments of developing countries in Africa need to have concrete policy measures that address the effects of lockdowns, ensure smooth reopening of the economies, and enhance recovery process.

9. The governments should strengthen the microenterprises and SMEs in order to enable the entrepreneurial development and sustainability.

10. All the stakeholders involved in COVID-19 mitigation should accelerate the vaccine rollout exercise to eliminate the pandemic in our midst. 


\section{REFERENCES}

African Union. (2020). Impact of the coronavirus (COVID-19) on the African economy. Regional Evaluation Report

Ayieko, Miltone Were and Timothy Njagi Njeru. (2020). Why COVID-19 is another blow for Kenya's food security. The Conversation journal. ISSN-135567.

Center for Global Development. (2020). the economic impact of COVID-19 in Africa: A round-up of week's analysis Report.

CDC. (2020). Africa CDC establishes continent-wide task force to respond to global coronavirus epidemic. Africa Centers for Disease Control and Prevention Report.

Durant, Isabelle and Pamela Coke-Hamilton. (2020). COVID-19 requires gender-equal responses to save economies. Journal of Global Health, 83 (5/6) 781-790

DW. Africa. (2020). No African country can face this crisis alone. World Bank ISSN 53142901

Du Toit A. (2020). Outbreak of a novel coronavirus. Nat Rev Microbiol.18:123. : doi:10.1038/s41579-0200332-0.

Euractiv. (2020). the last continent to face up COVID-19, Africa 'needs to wake up.

Gilbert M,Pullano G,Pinotti F, etal. Preparedness and vulnerability of African countries against importations of COVID-19: a modelling study. Lancet. 2020; 395: 871-877. doi:10.1016/S0140-6736(20)30411-6

International Labor Organization. (2018). Women and Men in the Informal Economy: A Statistical Picture Analysis.

ILO. (2020). Social protection responses to the COVID-19 crisis: Country responses and policy considerations report. 742337

ILO. (2020). COVID-19 and the World of Work, third edition.

International Monetary Fund. (2020). Policy responses to COVID-19. Available from: https://www.imf.org/en/Topics/imf-andcovid19/ Policy-Responses-to-COVID-19

Jaramillo, C.R. (2010). Do natural disasters have long-term effects on growth? SSRN. doi.org/10.2139/ ISSN1543453.

Jewell B, Mudimu E, Stover J, et al. (2020). Potential effects of disruption to HIV programmes in sub-Saharan Africa caused by COVID-19. The HIV Modelling consortium: results from multiple models. Pre-print. 2020. https ://doi.org/10.6084/m9.figsh are.12279 914.v1.

Maliszewska, Maryla and Mattoo, et al. (2020). Dominique, the Potential Impact of COVID-19 on GDP and Trade: A Preliminary Assessment Policy Research Working. World Bank. No. 9211, Available at SSRN: ssrn.com/abstract=3573211

Mark, Gill, Hovil, Lucy, Bueno Olivia and Genovese, Iolanda. (2020). Children on the move in East Africa: Research insights to mitigate COVID-19. Evidence for Action journal. UNICEF Publication New York

Mendelson M. (2020). Could enhanced influenza and pneumococcal vaccination programs help limit the potential damage from SARS-CoV-2 to fragile health systems of southern hemisphere countries this winter? International Journal for Infectious Diseases.2020;-94:32-33. doi:10.1016/j.ijid.2020.03.030

McKenzie B. (2020). The impact of COVID-19 on key African sectors. Journal of regional Economic Analysis 4 (1): 1-27

McKinsey. (2020). Safeguarding Europe's livelihoods. The covid-19 recovery journal. https://www.mckinsey.com/industries/publicsector/our-insights/safeguarding-europes-livelihoods-mitigating-the-employment-impactofcovid-19

Mining Review Africa. (2020). the impact of COVID-19 on the mining sector. Available from: https://www.miningreview.com/investment/theimpact-of-covid-19-on-the-global-mining-sector/

Mudie K, Tan MMJ, Kendall L, et al. (2019) Non-communicable diseases in sub-Saharan Africa: a scoping review of large cohort studies. J Glob Health. 2019; 9:020409. doi: 10.7189/ jogh. 09. 020409.

Mukhisa Kituyi et al (2020), impact of COVID-19 to trade and development: Transitioning to a new normal. United Nations Publication, Washington DC. ISBN: 978-92-1-113000-3 eISBN: 978-92-1-005448-5 
Mo Ibrahim Foundation. (2020) COVID-19 in Africa: A call for coordinated governance, improved health structures and better data in Africa: Available from: https://mo.ibrahim

Nachega JB, Seydi M, Zumla A. (2020). The late arrival of COVID-19 in Africa - Mitigating pan-continental spread. Clinical Infectious Diseases journal. doi:10.1093/ cid/ciaa353

OECD Development Matters. (2020). COVID-19 and beyond: How can Africa's health systems cope? Available from: https://oecddevelopmentmatters.org/2020/04/07/covid-19-and-beyond-howcan-africas-health-systems-cope/

Shabir Ahmad Lone \& Aijaz Ahmad. (2020) COVID-19 pandemic an African perspective, Emerging Microbes and Infections, 9:1, 1300-1308, DOI: 10.1080/22221751.2020.1775132

Skidmore, M., and H. Toya. (2002). Do natural disasters promote long run growth? Economic Inquiry journal 40(4): 664-687.

Toya, H., M. Skidmore, and R. Robertson. (2010). A reevaluation of the effect of human capital accumulation on economic growth using natural disasters as an instrument. Eastern Economic Journal 36(1): 120-137.

Tomasz Michalski, 2020 COVI19 the imact on developing economies

UN-Women. (2020). Gender equality in the wake of COVID-19. From Insights to Action Report UN-Women Data Hub. https://data.unwomen.org/publications/insights-action-gender-equality-wake-covid-19.

UNCTAD. (2020). Trade and Development Report 2020 - From Global Pandemic to Prosperity for All: Avoiding Another Lost Decade. United Nations. New York.

WHO. (2020). COVID-19 cases top 10,000 in Africa. Regular Report. Available from: https://www. afro.who.int/news/covid-19cases-top-10-000-africa.

WHO (2020) announces COVID-19 outbreak a pandemic. Europe, Geneva: World Health Organization,

WHO. (2020). A second COVID-19 case is confirmed in Africa. Available from: https:// www.afro.who.int/news/second-covid-19caseconfirmed-africa

World Bank (2020) policy research center The Potential Impact of COVID-19 on GDP and Trade: A Preliminary Assessment report. Washington DC.

Word Bank (2020). World Bank Group launches first operations for COVID-19 (coronavirus) emergency health support, strengthening developing country responses. Washington, DC: The World Bank. 